\title{
PERTAMBANGAN EMAS DAN SISTEM PENGHIDUPAN PETANI: STUDI DAMPAK PENAMBANGAN EMAS DI BOMBANA SULAWESI TENGGARA
}

\author{
Impact of Gold Mining on Farmers' Livelihood in Bombana
}

\author{
Sitti Rahma Ma'mun*) \\ Fakultas Pertanian Universitas Muhammadiyah Kendari, Jl. K.H. Ahmad Dahlan Kota Kendari, \\ Sulawesi Tenggara, 93111, Indonesia \\ ${ }^{*}$ E-Mail: rahma.mamun@gmail.com
}

\begin{abstract}
This study was aimed to analyze the impact of gold mining on livelihoods of farmers in rural area of Bombana District. The research used sustainable livelihoods approach which focus on vulnerability context faced by farmers around gold mine site and ownership of and access to capital assets which were influenced by mining activity, which in the end lead to increasing or decreasing livelihood outcome of farmers in the area. The study was done in three villages around the gold mine site. Data was gathered through combination of quantitative and qualitative method using sample survey, in-depth interview and focus group discussion. The result showed that there was declining on rice production due to decreasing of farm land and land degradation as a result of draught season that affected the area. Watu-Watu village was the worst in terms of the loss of natural assets compare to other villages. Policy, institution and process which were represented by government and mining companies have added local communities' exposure to vulnerability context they already faced. Livelihood diversification was chosen as coping strategy out of livelihood crisis due to the loss of productive assets caused by mining activities.
\end{abstract}

Keywords: gold, mining, farmers, livelihood, Bombana

\begin{abstract}
ABSTRAK
Penelitian ini dilakukan untuk menganalisa dampak kegiatan peambangan emas terhadap capaian penghidupan masyarakat di wilayah pedesaan kabupaten BombanA, dengan menggunakan pendekatan penghidupan yang berkelanjutan, yang menekankan pada konteks kerentanan yang dihadapi oleh masyarakat petani di sekitar wilayah penambangan serta pola kepemilikan dan akses terhadap asetaset penghidupan yang dipengaruhi oleh kegiatan penamanbangan, yang pada gilirannya dapat meningkatkan atau menurunkan kemampuannya dalam memperoleh capaian penghidupan yang lebih baik. Penelitian ini akan dilakukan di tiga desa di loaksi penambangan. Metode penelitian menggabungkan antara metode kualitatif dan kuantitatif. Metode kualitatif melalui Participatory Rural Appraisal (PRA), fokus grup diskusi dan wawancara mendalam, dan metode kuantitatif dengan menggunakan sample survey. Hasil penelitian menunjukkan adanya penurunan produksi pertanian di lokasi penelitian yang disebabkan berkurangnya lahan pertanian dan kerusakan lahan akibat kekeringan yang melanda lokasipenelitian. Desa Watu-Watu merupakan desa yang terparah dalam hal kehilangan aset penghidupan dibandingkan kedua desa lainnya. Keberadaan kebijakan, kelembagaan dan proses yang diwakili oleh pemerintah dan perusahaan penambangan merupakan faktor yang semakin menekan posisi masyarakat setempat dalam konteks kerentanan yang dihadapinya. Upaya masyarakat untuk keluar dari krisis penghidupan akibat berkurang akses terhadap aset penghidupan melahirkan diversifikasi sumber nafkah sebagai bentuk coping strategy, dan tidak semata-mata tergantung pada sektor pertanian, tetapi juga pada sektor non pertanian.
\end{abstract}

Kata kunci: tambang emas, penghidupan, petan, Bombana.

\section{PENDAHULUAN}

Tantangan untuk meraih pertumbuhan ekonomi yang tinggi dan mengejar ketertinggalannya dari wilayah lain di Indonesia tampaknya merupakan alasan bagi yang kuat bagi wilayah yang baru terbentuk untuk memanfaatkan sumberdaya alam (pertambangan) secara intensif, yang tidak jarang menimbulkan tekanan yang besar pada lingkungan. Meskipun dari beberapa pengalaman di wilayah lain di Indoensia, di mana eksplorasi pertambangan tidak selalu berbanding lurus dengan peningkatan kesejahteraan (Sukhyar 2008, Subiman dan Roesoesudarmo, 2010), sektor pertambangan tetap merupakan pilihan menarik untuk memacu pembangunan ekonomi daerah, tak terkecuali Kabupaten Bombana.

Menurut Kitula (2006), pertambangan memiliki sejumlah tahapan kegiatan, yang mana pada setiap tahapan tersebut berpotensi memberikan dampak yang buruk bagi lingkungan, sosial budaya, kesehatan dan keselamatan bagi para pekerja tambang dan masyarakat, berdasarkan kedekataannya dengan operasi tambang. Dalam banyak kasus yang terjadi di Indonesia, beberapa laporan hasil penelitian menunjukkan adanyakerusakan lingkungan akibat pencemaran air oleh merkuri yang digunakan dalam penambangan emas, seperti yang terjadi di Teluk Bayat Sulawesi Utara, Kasepuhan Jawa Barat atau di Lombak Barat NTB (Lasut dkk, 2009; Soemarwoto dan Ellen, 2009; dan Prasetyo dikk., 2010)), di mana dari ketiga contoh kasus tersebut pencemaran lebih disebabkan oleh penambangan rakyat tanpa izin (PETI). Dalam kasus Kasepuhan yang sebelumnya dikenal mengalami swasembada pangan, belakangan semakin menurun akibat peralihaan kepada kegiatan penambangan emas. Akibatnya banyak lahan yang terlantar. Tanaman sering dipanen lebih awal untuk menyesuaikan dengan jadwal penambangan emas, atau panen ditunda karena pemiliknya tersibukkan dengan 
kegiatan penambangan emas (Soemarwoto dan Ellen, 2009). Tambang emas bagi petani merupakan peluang untuk mencapai penghidupan yang lebih baik, karena bagi sebagian orang, usaha tani hanya menyediakan pangan sedangkan penambangan emas memberikan penghasilan yang jauh dari sekedar pangan (Cartier dan Burge, 2011; Soemarwoto dan Ellen, 2009, Zulkifli, 2013). Kasus Kasepuhan di atas tidak jauh berbeda dengan keadaan di Kabupaten Bombana. Sejak ditemukannya pada pertengahan tahun 2008 yang lalu, tambang emas Bombana memang tidak henti menuai perhatian banyak pihak. Kontroversi yang meliputi kawasan tambang emas, tarik-menarik kepentingan, perubahan sosial budaya serta kerusakan lingkungan hanya meruapkan sebagian kecil dari persoalan yang melingkupi kawasan tersebut. Penemuan tambang emas tersebut seolah menjadi sebuah berkah, harapan untuk mencapai pertumbuhan perekonomian yang lebih maju, masyarakat yang lebih sejahtera. Sebagai sebuah daerah yang relative baru terbentuk, kebutuhan untuk meningkatkan pendapatan asli daerah sangat besar, dan tambang emas, merupakan salah satu alternatif yang paling potensial untuk mendongkrak laju perekonomian daerah. Pembangunan sektor pertambangan untuk mendukung pembangunan ekonomi di Bombana perlu dikaji secara serius, terlebih lagi terhadap dampak yang ditimbulkannya pada masyarakat di sekitar wilayah penambangan. Dari berbagaipengalaman di seluruh Indonesia, peran perusahanperusahaan pertambangan dalam memajukan masyarakat lokal dipertanyakan (Subiman dan Resosudarmo, 2010). Kegiatan penambangan tersebut juga berpotensi bahkan telah melahirkan konflik kepetingan berbagai pihak; pemerintah, perusahaan penambangan dan kelompok-kelompok masyarakat (Amri, 2010). Padahal pertambangan seharusnya memberikan manfaat terbesar bagi masyarakat sekitar, karena mereka menerima dampak langsung dari kegiatan tersebut. Kajian terhadap penghidupan masyarakat di Kabupaten Bombana, khususnya pada wlayah di sekitar lokasi penambangan ini memiliki arti penting, untuk memberikan gambaran bagaimana penghidupan masyarakat pedesaan dibangun, serta coping strategy yang ditempuh masyarakat untuk mempertahankan penghidupannya, untuk beradaptasi terhadap perubahan sebagai dampak dari kegiatan penambangan emas.

Penelitian ini bertujuan untuk menganalisa dampak penambangan emas terhadap terhadap capaian penghidupan masyarakat wilayah pedesaan Kabupaten Bombana, dengan menggunakan pendekatan kerangka kerja penghidupan yang berkelanjutan (sustainable livelihods approach/SLA) melalui kajian terhadap: 1) Pola kepemilikian dan akses terhadap sumberdaya yang dibutuhkan dalam mendukung penghidupan yang berkelanjutan, 2) Pola dan strategi penghidupan individu rumah tangga dan pereubahannya dalam kurun waktu 5 dan 10 tahun terakhir, 3) Konteks kerentanan yang dihadapi masyarakat pedesaan, dan 4) Konteks kelembagaan dengan penekanan pada faktor yang menghambat pilihan dan peluang penghidupan bagi masyarakat pedesaan dalam adaptive atau coping strategy untuk mengatasi dampak kegiatan penambangan emas.

Pilihan penggunaan SLA dalam penelitian ini didasarkan pada kajian literatur yang menunjukkan kelebihan SLA dalam memetakan kondisi masyarakat wilayah pedesaan, khususnya seputar persoalan yang menyebabkan mereka berada dalam kemiskinan. Penelitian yang dilaksanakan dengan menggunakan kerangka kerja Sustainable Livelihoods telah memberikan pemahaman yang kuat terhadap penghidupan masyarakat pedesaan yang beragam dan kompleks dalam konteks tertentu (Brock, 1999). Sebelum ini, pemahaman tentang bagaimana masyarakat di negara berkembang, khususnya masyarakat pedesaan menghasilkan penghidupannya dipandang sangat sederhana. Padahal kenyataannya, bagaimana penghidupan dihasilkan sangat kompleks, beragam, dinamis dan menggunakan kombinasi berbagai sumberdaya yang tersedia (Chambers and Conway, 1992; Chamber 1995). Pendekatan penghidupan yang berkelanjutan yang telah berkembang lebih dari satu dekade ini memberikan kerangka kerja yang lebih kompleks untuk memahami bagaimana akses terhadap sumberdaya dan penghidupan rumah tangga dalam konteks masyarakat tertentu berinteraksi (Carney, 1998; DFID, 2000; Schoones, 1998). Meskipun terdapat beberapa kritik terhadap pendekatan ini, Schoones (2006) menegaskan bahwa perspektif livelihoods menawarkan kaca mata yang penting dalam melihat berbagai pertanyaan (persoalan) pembangunan pedesaan yang kompleks.

Salah satu definisi livelihoods yang digunakan secara luas adalah definisi yang dikemukakan oleh Carney (1998), yang mengadaptasikan dari karya Chamber dan Conway (1992), sebagai berikut: "Livelihoods comprises the capabilities, assetes (including both material and social resources) and activities required for a means of living. A livelihoods is sustainable when it can cope with and recover from stresses and shocks, maintain or enhance its capabilities and assets, while not undermining the natural resource base."

Definisi di atas mencakup dua aspek, yaitu livelihoods atau penghidupan yang terdiri dari tiga elemen, yakni kemampuan, asset dan kegiatan yang dikombinasikan untuk dapat bertahan hidup atau memperoleh penghidupan yang lebih baik, bahkan memperoleh kesejahteraan. Aset dimaksud terdiri atas sumber daya alam, sumber daya manusia, sumberdaya fisik, sumberdaya finansial dan sumberdaya sosial (Carney, 1998; Schoones, 1998). Dalam hal ini, aset tidak sekedar sumberdaya yang digunakan untuk membangunan penghidupan, akan tetapi ia adalah modal yang memberi manusia kemampuan untuk menjadi dan berbuat (Bebbington, 1998). Aspek yang kedua adalah sustainability atau keberlanjutan, yang menekankan kepada kemampuan untuk bertahan dan pulih dari goncangan, dan kelestarian sumberdaya alam yang mana masyarakat menggantungkan sebagian penghidupan mereka kepada sumberdaya alam tersebut. Kerangka kerja sebagaimana disebutkan di atas menampilkan sejumlah faktor yang saling berhubungan, yang mempengaruhi strategi penghidupan (livelihoods strategy) yang ditempuh (dalam skala rumah tangga atau skala yang lebih luas seperti desa, kecamatan atau kabupaten), dan hasil yang diperoleh (livelihoods outcome) (Bennet, 2010). Satu aspek kunci pada pendekatan penghidupan (livelihoods approach) adalah bagaimana memahami profil akses, dan konsekuensinya terhadap ketersediaan aset, berubah sepanjang waktu, khususnya bagaimana peningkatan dan penurunan nilai dari aset tersebut mempengaruhi penghidupan rumah tangga (Reddy dan Sousan, 2004).

Ketiga komponen kerangka kerja di atas, konteks kerentanan (vulnerability context), asset penghidupan (livelihood assets) serta kebijakan, kelembagaan dan proses (policies, institutions and process) akan menentukan strategi penghidupan (livelihood strategies) yang ditempuh oleh individu dan masyarakat. Strategi penghidupan merupakan serangkaian kegiatan dan pilihan yang biasanya diadakan atau ditempuh oleh masyarakat pada waktu stabil atau dalam keadaan aman dan damai dalam rangka mencapai tujuan penghidupannya (FAO, 2007). Strategi yang ditempuh dapat berupa kegiatan yang bergantung pada sumberdaya alam (seperti pertanian, kehutanan, perikanan, dll.) atau pada sumberdaya selain alam (seperti pedagangan, jasa, dsb.), untuk meghasilkan capaian penghidpan (livelihood outcome) yang dapat berupa ketahanan pangan, kesejahteraan, status social dan kelestarian sumberdaya alam. alam kasus 
masyarakat pedesaan Bombana, capaian penghidupan yang dihasilkan bisa positif atau negatif, tergantung dari pilihan strategi yang ditempuh untuk beradaptasi dengan, atau mengatasi perubahan yang terjadi akibat adanya penambangan emas.

\section{METODE PENELITIAN}

Penelitian ini dilaksanakan di dua desa di sekitar wilayah penambangan yang dipilih secara sengaja, berdasarkan pertimbangan bahwa ketiga desa tersebut terletak di sekitar wilayah pertambangan yang mayoritas sebagian besar masyarakatnya menggantungkan kehidupan mereka terhadap sektor pertanian. Kedua desa tersebut adalah Desa WatuWatu di Kecamatan Lantari Jaya, dan Desa Wumbubangka di kecamatan Rarowatu Utara. Pengumpulan data dilakukan dengan menggabungkan teknik sample survey dengan pengumpulan data kualitatif dengan Focus Group Discussion (FGD). Kedua metode ini tidak berdiri sendiri akan tetapi saling melengkapi satu sama lain. Pemilihan rumah tanggasampel untuk keperluan survei dilakukan secara acak sederhana dengan mengambil jumlah 30 sampel. Untuk memperoleh data pada tingkat rumahtangga tersebut, disusun sebuah kuisioner, yang meliputi data di antaranya: demografi, aset lahan dan pendapatan usaha tani, sumber-sumber penghasilan non pertanian, dan aset rumah tangga, termasuk aset produksi dan konsumsi. Sementara itu untuk melengkapi data yang diperoleh melalui survei rumah tangga dilakukan wawancara focus group discussion dan wawancara mendalam dengan informan kunci. Data yang terkumpul melalui kuisioner kemudian diverifikasi dan diolah dengan menggunakan SPSS. Data hasil penelitian ini akan dianalisa dengan menggunakan statistik deskriptif frekuensi tabulasi silang,untuk melihat perbedaan sebelum dan setelah kegiatan penambangan emas dilakukan di wilayah tersebut.

\section{HASIL DAN PEMBAHASAN}

Kabupaten Bombana adalah satu wilayah di Provinsi Sulawesi Tenggara hasil pemekaran dari Kabupaten Buton, yang dibentuk berdasarkan UU No, 29 tahun 2003 tertanggal 18 Desember 2003. Meskipun terdapat pergeseran tata ruang, di mana wilayah pertanian sebagian telah beralih menjadi wilayah penambangan, sektor pertanian tetap menjadi penyumbang utama terhadap PRDB Kabupaten Bombana, namun kontribusi tersebut menunjukkan tren yang terus menurun. Sejak tahun 2006 sampai dengan 2010, kontribusi sektor pertanian terhadap pendapatan domestik regional bruto (PDRB) Kabupaten Bombana menurun dari $53,74 \%$ menjadi $48,70 \%$. Di sisi lain, kontribusi sektor pertambangan mengalami peningkatan dari $3,27 \%$ pada tahun 2006 menjadi 4,94\% pada tahun 2010. Ini bearrti bahwa dalam kurun waktu 5 tahun kontribusi sektor pertambangan terhadap PDRB namengalami kenaikan sebesar $1,22 \%$.

Kecamatan Lantari Jaya dan Kecamatan Rarowatu Utara adalah dua di antara beberapa kecamatan di mana wilayah penambangan berada, dan yang paling merasakan dampak kegiatan penambangan. Kecamatan Lantari Jaya sendiri merupakan daerah pemekaran yang berasal dari sebagian wilayah Kecamatan Rarowatu Tengah dan Kecamatan Rarowtau Utara, berdasarkan Peraturan Daerah No. 21 Tahun 2008. Mayoritas masyarakat di kecamatan ini menggantungkan hidupnya pada sektor pertanian. Dari total 3.264 ha lahan yang diusahakan, tanaman pangan mendominasi dengan luas 2.744 ha. Sebagian besar lahan tersebut atau 1.800 ha adalah sawah tadah hujan, 629 ha sawah beririgasi setengah teknis, dan sisanya 345 ha merupakan sawah dengan pengairan sederhana.
Sementara itu di Kecamatan Rarowatu Utara, dari total lahan pertanian 14.994 ha, 1.707 ha di antaranya adalah lahan sawah yang terdiri dari 1.300 ha sawah tadah hujan dan 407 ha sawah beririgai sederhana (BPS, 2012). Kondisi iklim yang cenderung kering dan terbatasnya sumber air irigasi yang berasal dari Bendung Langkowala, menyebabkan sebagian besar lahan sawah hanya mengalami satu kali musim tanam. Adapun bagi petani yang melakukan penanaman dua kali dalam setahun umumnya menggunakan sumber air yang berasal dari sumur bor hasil swadaya petani.

Produksi pertanian mengalami penurunan drastispada tahun 2009. Selain disebabkan kekeringan akibat kemarau panjang, berkurangnya luas panen juga disebabkan karena sebagian petani meninggalkan lahan pertanian mereka dan mencoba peruntungan menjadi penambang emas, meskipun tanpa disertai pengalaman yang memadai, untuk memperoleh hasil yang instan. Tidak seperti kegiatan bertani yang membutuhkan proses panjang untuk memetik hasilnya, penghasilan dari kegiatan menambang dapat diperoleh bahkan dalam kurun waktu sehari. Tidak dapat dipungkiri bahwa emas telah mebawa berkah tersendiri bagi masyarakat. Peningkatan penghasilan sesaat yang dirasakan masyarakat di wilayah penambangan dapat dilihat dari meningkatnya kepemilikan kendaraan roda dua sejak tahun 2008 (Zulkarnain, dkk., 2010). Meskipun demikian hal ini tidak berlangsung lama, karena sejak pertengahan Maret tahun 2009, masyarakat tidak lagi leluasa melakukan aktivitas penambangan. Adapun mereka yang masih melakukan kegiatan penabamgan liar hanya memperoleh hasil yang minim dibandingkan sebelumnya, sehingga timbul istilah di tengahtengah masyarakat, bila dahulu mereka menanam padi untuk membeli emas, maka sekarang ini mereka mencari emas untuk membeli beras.

\section{Corak Penghidupan Lokasi Penelitian}

\section{Desa Watu-Watu}

Desa Watu-Watu mencakup 15,72\% dari wilayah Kecamatan Lantari Jaya, atau seluas $44,80 \mathrm{~km}^{2}$ dengan jumlah penduduk 919 jiwa, terdiri dari 249 KK yang tersebar di tiga dusun. Sebagian besar dari masyarakat desa berasal dari suku asli Morunene, dan sebagiannya lagi suku Bugis dan lainnya. Desa ini dapat dicapai dengan kendaraan roda empat melalui jalan tanah bergelombang melewati Desa Langkowala. Memasuki desa ini, suasana penambangan emas sangat terasa. Sepanjang jalan di sebelah kanan yang terlihat adalah lahan kering dengan tanaman Jambu Mete, dan rumah penduduk yang terlihat lebih jarang dibandingkan Desa Langkowala. Sedangkan di sebelah kiri sepanjang jalan terlihat gundukan tanah galian, bahkan sebagian letaknya tidak jauh di belakang rumah warga. Desa Watu-Watu memiliki lahan sawah seluas 174 ha, sedangkan sisanya terdiri dari 101 ha lahan kering dan 32 ha lagi lahan lainnya. Sebelum ini, sumber pengairan bagi sawah petani adalah tadah hujan yang didukung saluran pengairan sederhana yang berasal dari Bendung Langkowala.

Hasil diskusi kelompok terfokus bersama warga desa, diketahui sejak tahun 2009, luas sawah yang masih berproduksi sangat jauh berkurang. Hal ini lebih disebabkan karena kemarau panjang dan kurangnya pasokan air dari Sungai Langkowala. Dahulu, meskipun curah hujan tidak begitu tinggi, adanya Bendung Langkowala yang dibangun tahun 1992 mampu menaikkan permukaan air dan menahan air hingga 1 minggu. Akan tetapi keadaan yang dialami saat ini sangat jauh berbeda. Terlebih sejak sumber air dan hutan mulai rusak. Sebelumnya, sejak tahun 1994 Desa Watu-Watu merupakan bagian dari wilayah 
Hutan Tanaman Industri PT. Barito Timber Pasifik. Akan tetapi karena pertumbuhan yang kurang maksimal, perusahaan tersebut keluar pada tahun 2009. Keberadaan perusahaan tersebut mendapat apresiasi yang baik dari masyarakat sekitar, karena banyak membawa manfaat bagi mereka.

\section{Desa Wumbubangka}

Desa Wumbubangka meliputi wilayah seluas $176,54 \mathrm{~km}^{2}$ dengan populasi sebanyak 2.206 jiwa dan $237 \mathrm{KK}$ yang tersebar di empat dusun. Penduduk Desa Wumbumbanga sebagian berasal dari Muna dan Konawe Selatan. Desa ini dapat dicapai dengan roda empat kurang lebih 15 menit dari jalan utama, dengan kondisi jalan merupakan jalan pengerasan. Perjalanan menyusuri Desa Wumbubangka mencapai bagian tempat di mana lokasi tambang milik PT. PLM berdiri, masih terlihat bekas-bekas terpal para pendatang, yang sebagian digunakan warga desa untuk menambal rumahnya. Di sebagian tempat tampak bekas-bekas tenda yang ditinggalkan. Sama seperti Desa Watu-Watu, desa ini pun belum seluruhnya dialiri listrik.

Sebelum tahun 2008, sektor pertanian merupakan sumber mata pencarian utama warga desa. Data Statistik pada tahun 2011 menunjukkan bahwa di Desa Wumbubangka tidak terdapat lahan sawah, melainkan lahan kering seluas 225 ha dan lahan pertanian lainnya 213 ha (BPS, 2012). Hal ini sejalan dengan apa yang diakui oleh Kepala Desa pada saat observasi awal, bahwa dalam 5 tahun terakhir, produksi pertanian (padi) di Desa Wumbubangka hampir tidak ada. Kekeringan yang terjadi serta rusaknya irigasi yang bersumber dari Sungai Langkowala menyebabkan sebagian masyarakat kehilangan mata pencaharian mereka, dan kini kembali berladang, atau bermitra dengan perusahaan tambang bagi yang beruntung mendapatkannya.

\section{Dampak Tambang terhadap Penghidupan Masyarakat}

\section{Kontenks Kerentanan di Wilayah Penambangan}

Konteks kerentanan atau vulnerability context membentuk lingkungan eksternal di mana masyarakat berada (DFID, 1999). Bagaimana masyarakat membentuk penghidupannya serta akses terhadap aset yang dimilikinya sangat ditentukan oleh konteks kerentanan yang melingkupinya, berupa shock dan trend.

Chambers dan Conway (1992) menyatakan bahwa shock adalah guncangan yang biasanya terjadi secara tiba-tiba, tidak dapat diduga, dan menghancurkan, seperti kebakaran, banjir, epidemi. Shock dapat menghancurkan aset penghidupan yang dimiliki seseorang. Shock juga dapat memaksa seseorang meninggalkan rumahnya atau menjual aset yang dimilikinya (seperti lahan) sebagai bagian dari strategi bertahan hidup. (DFID, 1999). Di sisi lain, trend merupakan kecenderungan yang umumnya dapat diperkirakan namun pengaruhnya tidak kalah merugikan apabila gagal diantisipasi dengan baik.

Persoalan utama yang mencuat dalam diskusi kelompok terfokus (FGD) di tiga desa adalah masalah kepemilikan lahan. Pemberian izin Usaha Pertambangan (IUP) dan pengambilalihan lahan sepihak tanpa kesepakatan terlebih dahulu meresahkan masyarakat desa di wilayah penambangan, khususnya Desa Wumbubangka dan Desa Watu-Watu di mana lokasi tambang berada. Di satu sisi, kegiatan penambangan oleh perusahaan pemegang IUP telah menghancurkan sumber-sumber penghidupan masyarakat, sementara di sisi lain peluang kerja yang ditawarkan bagi masyarakat setempat sangat terbatas, mengingat perusahaan penmbangan besar umumnya bersifat

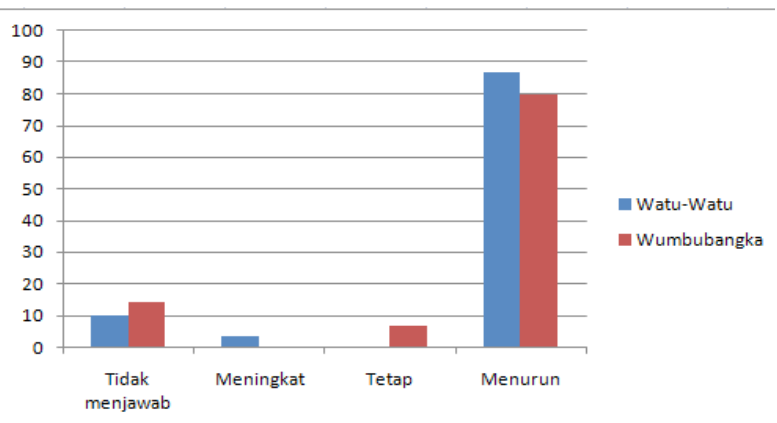

Grafik 1. Persentasi Perubahan Produksi Pertanian 5 s.d. 10 Terakhir

padat modal yang tidak terlalu banyak membutuhkan tenaga kerja. Keresahan warga sangat beralasan. Lahan yang selama ini diolah sebagai sumber mata pencaharian utama telah musnah, bahkan tanah yang mereka tinggali selama beberapa generasi pun terancam akan diambil alih sewaktu-waktu karena masuk dalam wilayah IUP. Perkataan bahwa 'suara orang kecil selalu terabaikan’ tampak nyata di wilayah ini.

Bagi para petani yang lahannya tidak masuk ke dalam wilayah IUP seperti Desa Langkowala, kegiatan penambangan juga membawa dampak serius dengan rusaknya sumber air Sungai Langkowala yang selama ini menjadi sumber pengairan untuk mencukupi curah hujan yang tidak memadai. Bendung Langkowala yang dibuat untuk meninggikan permukaan air Sungai Langkowala yang mengalir ke sawah warga tidak lagi berfungsi, karena perusahaan penambangan telah membendung air di hulu untuk kepentingan penambangan. Akibatnya produksi padi pun sangat menurun. Penurunan produksi pertanian dibandingkan dengan 5 sampai dengan 10 terakhir juga terjadi di Desa Watu-Watu dan Desa Wumbubangka sebagai yang disajikan pada Grafik 1berikut.

Sebagian besar penurunan produksi di atas disebabkan kekeringan akibat kemarau panjang, mengingat sebagian besar lahan sawah merupakan sawah tadah hujan, dan juga karena curah hujan yang tidak mencukupi, sedangkan Bendung Langkowala tidak dapat lagi diharapkan untuk menambah pasokan air bagi petani. Demikian halnya petani di Desa Wumbubangka yang dahulu juga memanfaatkan air dari Sungai Langkowala mengeluhkan hal yang sama, karena sumber air yang mereka gunakan telah rusak, bahkan tidak diketahui lagi mana badan sungai yang asli.

\section{Akses terhadap Aset Penghidupan}

Kepemilikan dan akses terhadap aset penghidupan di Desa Wumbubangka sedikit lebih baik daripada Desa Watu-Watu sebagaimana yang digambarkan dalam pentagon aset di atas. Meskipun terdapat kerusakan aset sumber daya alam di Desa Wumbubangka, akan tetapi akses untuk memanfaatkan hasil hutan dan sungai masih terbuka, sebagaimana yang ditunjukkan dari hasil survei dan diskusi kelompok di desa tersebut. Berbeda dengan yang dialami oleh masyarakat di Desa Watu-Watu, di mana akses terhadap sumberdaya alam, baik hutan maupun sungai ditutup oleh perusahaan pemegang KP. Demikian juga pada sumberdaya fisik, meskipun kedua desa sama-sama terjadi pengambilalihan lahan pertanian, namun sampai pada saat survei dilakukan, penguasaan lahan milik masyarakat lebih banyak terjadi di Desa Watu-Watu. Hasil survey menunjukkan pula bahwa di atas 50\% masyarakatmemilikilahan di bawah 1 ha. Dari segi sumberdaya sosial, hasil survey menunjukkan bahwa masyarakat Desa Watu-Watu lebih aktif untuk membangun aset 


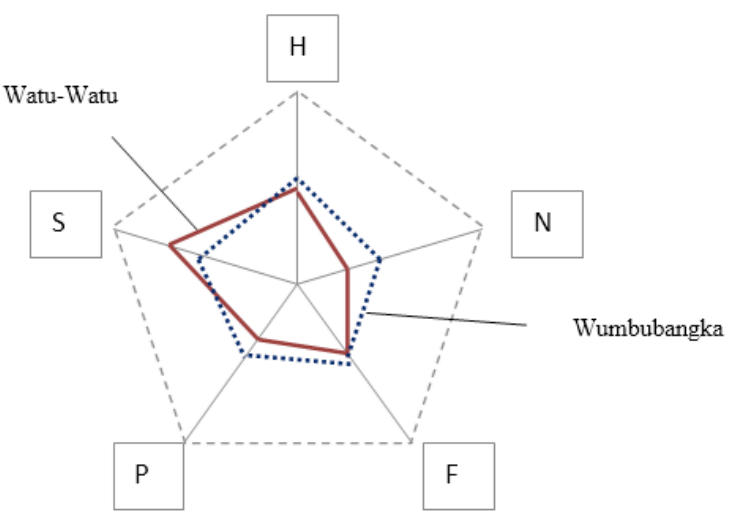

Gambar 1. Aset Pentagon Kebijakan, dan Kelembagaan Struktur dan Proses

sosial karena dapat memberikan manfaat pada saat dibutuhkan.

Struktur dan Proses dalam kerangka kerja Penghidupan yang Berkelanjutan adalah lembaga, organisasi, kebijakan dan peraturan yang mempengaruhi penghidupan masyarakat (DFID, 1999). Dalam hal ini struktur mencakup organisasi atau lembaga yang ada di tengah-tengah masyarakat yang paling mempengaruhi penghidupan mereka. Sedangkan proses menggambarkan langkah, peran atau kegiatan apa yang dilakuan oleh lembaga tersebut dalam menjalankan fungsinya.

Pembahasan pada bagian ini tidak dimaksudkan untuk menggabarkan secara detail mengenai fungsi, peran dan kebijakan yang diambil pemerintah serta perusahaan penambangan di lokasi penelitian. Bagian ini lebih untuk menggabarkan bagaiman keahadiran organisasi atau lembaga dan peran yang dimainkannya dapat sangat mempengaruhi penghidupan masyarakat di mana organisasi atau lembaga tersebut memainkan perannya.

Bagi masyarakat di sekitar lokasi penambangan, khususnya di lokasi penelitian, peran pemerintah dan perusahaan penambangan yang beroperasi di wialayah tersebut sangat ditunggu. Pemerintah, diharapkan mampu melindungi masyarakat kecil, memberi kesempatan bagi mereka untuk mencapai penghidupan yang lebih baik, dengan kebijakan dan program pembangunan yang lebih berpihak pada kepentingan masyarakat luas. Di sisi lain, bagi perusahaan penambangan yang bekerja di wilayah tersebut, seharusnya memberikan hak-hak masyarakat berupa kompensasi yang sesuai atas dampak yang dirasakan oleh masyarakat, dalam wujud program-program yang yang dapat menunjang pencapaian penghidupan yang berkelanjutan bagi masyarakat setempat.

Dari hasil wawancara mendalam dengan masyarakat di tiga desa lokasi penelitian, kekecewaan dan kemarahan terhadap peran pemerintah yang kurang berpihak terhadap masyarakat kecil sangat besar. Penerbitan IUP yang tidak memperhatikan hakhak masyarakat yang telah mendiami wilayah tersebut, bahkan menjadi tumpuan sumber penghidupan mereka, dirasakan sangat merugikan. Ditambah lagi tidak pernah adanya kompromi atau kesepakatan dengan masyarakat, membuat masyarakat desa merasa semakin terpinggirkan dari terusir dari tempat mereka sendiri. Di sisi lain, perusahaan penambangan yang seharusnya lebih aktif memberikan kontribusi bagi masyarakat di wilayah tersebut tidak menjalankan kewajibannya, bahkan justru menambah beban masyarakat.

\section{Strategi dan Capaian Penghidupan}

Strategi penghidupan menggambarkan uapaya masyarakat

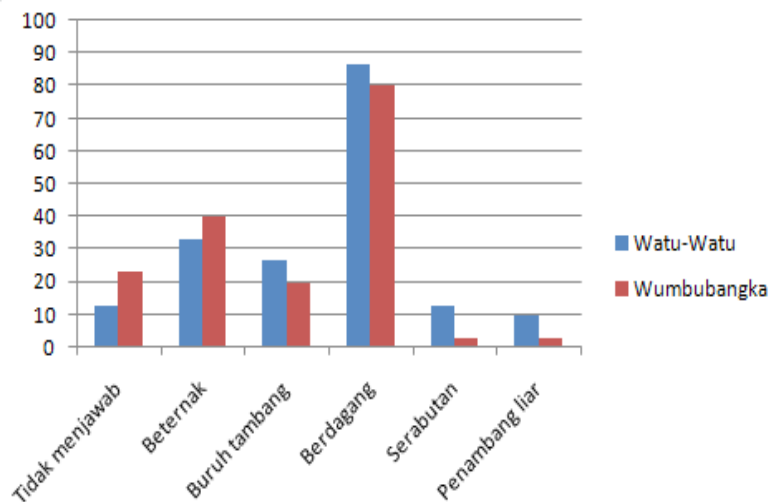

Grafik 2. Alternatif Sumber Penghidupan Lokal

dalam usaha mempertahankan hidupnya dan mencapai tingkat penghidupan yang lebih baik. Respon masyarakat terhadap kontenks kerentanan yang dihadapinya umumnya berdasarkan pengetahuan yang dimiliki dan pengalaman mempraktekkan pilihan tersebut dalam jangka waktu yang lama, yang terbukti efektif ketika menghaapi masa sulit, serta didukung oleh asset/ modal yang dimiliki. Beternak adalah usaha yang umum dipilih sebagai kegiatan sampingan petani di luar musim tanam. Usaha ternak menjadi semakin penting artinya pada saat lahan pertanian tidak lagi bisa diandalkan untuk menghasilkan produksi. Pola atau strategi yang dibangun oleh masyarakat di sekitar wilayah penambangan akan sangat tergantung pada kemampuan (capability) yang dimiliknya untuk memperoleh capaian penghidupan yang lebih baik.Sen (2005) mendefinisikan capability sebagai "what people can do or be", yakni apa yang bias dilakukan atau dicapai seseorang, yang tentu saja akan sangat tergantung terhadap aset yang dimilikinya, serta peluang dan kebebasan memilih peluang tersebut. Seseorang yang memiliki pendidikan yang lebih baik, kondisi kesehatan yang lebih baik, dan lain-lain, maka dapat diharapkan akan meraih sesuatu yang lebih baik dalam hidupnya (Sen, 1984). Dengan tingkat pendidikan tertinggi SMA hanya sebanyak 7\% di kedua desa, dapat dipahami bahwa peluang dan kebebasan mereka meraih peluang di luar sector pertanian yang mereka geluti untuk penghidupannya tersebut sangat terbatas.

Hasil wawancara dengan masyarakat di desa penelitian, menjadi buruh tambang lebih menguntungkan. Akan tetapi akses untuk memperoleh kesempatan itu terbatas, sehingga sebagian lainnya yang tidak memilliki modal untuk beternak atau mengerjakan pekerjaan lain, menjadi penambang liar adalah alternatif upaya untuk menyambung nafkah keluarga, meski dengan resiko setiap hari harus berhadapan dengan petugas keamanan perusahaan.Alternatif sumber penghidupan selengkapnya dapat dilihat pada Grafik 2.

Diversifikasi penghidupan yang ditempuh oleh masyarakat di lokasi penelitian lebih disebabkan oleh kebutuhan yang didorong oleh perubahan kondisi di lingkungan sektarnya. Ellis (2000) mengemukakan bahwa alasan individu atau rumah tangga yang melakukan diversifikasi sebagai strategi penghidupan karena kebutuhan, akan berakibat pada individu atau rumah tangga tersebut melakukan pekerjaan serabutan atau pekerjaan dengan produktivitas rendah dengan prospek yang kurang menjanjikan, sebagaimana dijumpai di lokasi penelitian.

Dampak penambangan terhadap kondisi ekonomi secara keseluruhan, $35 \%$ menyatakan terjadinya penurunan kondisi ekonomi, dan $40 \%$ mengatakan tidak adanya perubahan. 
Tabel 1. Perubahan Kondisi Ekonomi RT Berdasarkan Alternatif Pekerjaan Lain

\begin{tabular}{lrrrrr}
\hline \multirow{2}{*}{ Pekerjaan lain } & \multicolumn{4}{c}{ Kondisi Ekonomi } & \\
\cline { 2 - 5 } & 1 & 0 & 5 & 5 & 11 \\
\hline Tidak ada & 1 & 1 & 6 & 14 & 22 \\
Beternak & 0 & 4 & 10 & 0 & 14 \\
Buruh tambang & 0 & 1 & 2 & 1 & 4 \\
Berdagang & 0 & 0 & 4 & 1 & 5 \\
Serabutan & 0 & 2 & 2 & 0 & 4 \\
Penambang liar & 2 & 8 & 29 & 21 & 60 \\
\hline Total & & & & & \\
\hline
\end{tabular}

Salah satu alasan yang dikemukakan oleh responden yang mengalami penurunan kondisi perekonomian, karena pada saat ini mereka tidak lagi memiliki akses untuk melakukan kegiatan penambangan seperti dulu. Sebagian yang kondisi ekonominya tetap, karena mereka masih dapat bekerja sebagai buruh tambang, atau memiliki pekerjaan lain yang tidak menetap, namun mampu memenuhi kebutuhan hidup diri dan keluarganya.

Kelompok masyarakat yang menyatakan terjadinya peningkatan pendapatan adalah mereka yang memiliki penghasilan berada di atas Rp 5 juta. Hal ini mengindikasikan bahwa semakin tinggi penghasilan, semakin besar kemungkinan dan untuk seseorang untuk memperbaiki kondisi perekonomiannya, terlebih pada saat menghadapi krisis. Sebaliknya, kelompok yang memiliki potensi yang rendah untuk melakukan subtitusi antar jenis sumberdaya dan pola nafkahnya, akan lebih rentan terhadap guncangan. Secara umum, kegiatan penambangan telah memebrikan dampak pada kondisi perekonomian masyarakat.

Perubahan kondisi ekonomi yang ditampilkan pada Tabel 1, menunjukkan bahwa kelompok masyarakat yang hanya menggantungkan hidupnya sebagai petani saja tidak mengalami peningkatan dari segi ekonomi, demikian pula kelompok masyarakat yang memiliki alternatif pekerjaan tidak tetap (serabutan).Sementara itu, kelompok yang memilih usaha ternak juga mengalami penurunan. Hal ini disebabkan usaha ternak yang mengalami penurunan, yang disebabkan penyakit, kehilanga ternak atau kematian ternak di bekas lubang galian tambang. Meskipun demikian, dari hasil diskusi dengan masyarakat di tiga desa, ternak merupakan pilihan usaha potensial yang menjanjikan harapan di masa mendatang.

Uraian di atas mengindikasikan bahwa meskipun kegiatan penambangan emas di Kabuapten Bombana diklaim telah merugikan rakyat, namun daya tarik emas masih tetap tinggi. Meskipun demikian, pembukaan pertambangan rakyat tampaknya bukan merupakan pilihan yang mudah bagi pemerintah, mengingat pengalaman yang lalu di mana kegiatan penambangan oleh masyarakat yang tanpa dibekali pengetahuan mengenai praktek penambangan yang baik telah membeikan dampak terhadap degradasi lingkungan yang sangat besar.

Kegiatan penambangan oleh perusahaan telah menyebabkan masyarakat kehilangan lahan pertanian yang menjadi tumpuan hidup mereka. Penerbitan IUP bagi beberapa perusahaan penambangan, ditindaklanjuti oleh perusahaan dengan pengambilalihan lahan milik masyarakat dan menempatkan petugas keamanan untuk menghalangi akses masyarakat terhadap lahan yang masuk dalam wilayah IUP tersebut. Sementara itu, kompensasi yang dijanjikan dan program pengembangan masyarakat yang terkena dampak dari kegiatan penambangan emas hingga pada saat itu belum ada kejelasan. Padahal lahan merupakan aset vital bagi penghidupan masyarakat, dan perlu mendapatkan pembayaran yang sesuai pada orang (pemilik lahan) yang tepat (Kidido, dkk., 2015).

Pengambilalihan lahan masyarakat yang terjadi, jika tidak disertai dengan transparansi mengenai kompensasi dan programprogram pengembangan masyarakat lokal, dikhawatirkan akan menimbulkan konflik terbuka, baik antar masyarakat dengan pihak perusahaan, ataupun dengan pemerintah. Hal tersebut sangat mungkin terjadi, mengingat saat ini telah tersimpan bibitbibit kecemburuan sosial dan kekecewaan mendalam akan sikap abai perusahaan dan pemerintah terhadap masyarakat lokal.

Secara keseluruhan, keberadaan penambangan memang memberikan pengaruh yang signifikan bagi masyarakat. Upaya masyarakat mengatasi dampak kegiatan penambangan terhadap penghidupannya (copyng strategy) mendorong diversifikasi penghidupan, yang sesungguhnya dapat menciptakan peluangpeluang baru di luar sektor pertanian. Usaha untuk mempertahankan sektor pertanian, khususnya usaha tani padi sawah, memang menghadapi tantangan yang besar, dari segi suplai kebutuhan air bagi produksi pertanian. Rusaknya vegetasi dan sumber air di DAS yang terletak di hulu Sungai Langkowala akibat kegiatan penambangan bukan satu-satunya faktor penyumbang musibah kekeringan yang terjadi di Kecamatan Lantari Jaya dan Rarowatu Utara. Hasil penelitian Tim Kajian Tambang LIPI menunjukkan bahwa karakteristik geologi dan geomorfologi wilayah tersebut mengindikasikan bahwa sumber daya air relatif terbatas, kalaupun ada, umumnya hanya berupa air tanah bebas/dangkal Ditambah lagi dengan fakta bahwa keberadaan air sungai di wilayah ini sangat ditentukan oleh curah hujan (Pudjastuti, 2010). Hal senada juga dikemukakan dalam diskusi kelompok terfokus di Desa WatuWatu. Salah seorang peserta yang sebelumnya adalah petugas HTI, menyebutkan salah satu penyebab pertumbuhan tanaman tidak maksimal adalah karena sifat tanah yang kedap air. Dari hasil diskusi itu juga diketahui bahwa fungsi Bendung Langkowala selama ini sebenarnya hanya untuk menaikkan permukaan air sungai pada musim hujan, sehingga dapat dipergunakan untuk mengairi sawah masyarakat.

Kebijakan pengembangan wilayah setempatmemang memerlukan pertimbangan serius dan hati-hati, karena di beberapa wilayah, kegiatan penambangan emas terbukti mampu meningkatan kesejahteraan masyarakat di sekitar wilayah tersebut (Cartier dan Burger, 2011; Fisher, dkk., 2009; Zulkifli, 2013). Apapun yang menjadi pilihan pemerintah pada akhirnya, akan selalu ada trade off antara sektor pertanian dan sektor pertambangan, yang pada gilirannya akan berdampak pada penghidupan petani. Apakah masyarakat petani akan beralih sepenuhnya menjadi masyarakat penambang, ataukah menjadi kedua-duanya, petani sekaligus penambang, ataupun tidak kedua-duanya. Pertimbangan potensi lokal, dan upaya pencapaian ketahanan pangan dan peningkatan kesejahteraan sosial ekonomi masyarakat setemapt seharusnya menjadi pertimbangan utama, dan tidak melulu dari sisi keuntungan pendapatan asli daerah (PAD).

\section{KESIMPULAN DAN SARAN}

\section{Kesimpulan}

Meskipun tidak berlangsung lama, keberadaan penambangan 
pada tahap awal memberikan manfaat yang besar, dan kesempatan untuk mengumpulkan aset rumah tangga dan modal bagi. masyarakat di sekitar wilayah penambangan. Pasca berakhirnya izin pertambangan bagi rakyat dan kebijakan pemerintah mengeluarkan IUP, berdampak pada hilangnya asetaset penting petani yang selama ini menjadi tumpuan nafkah bagi keluarga. Hilangnya aset lahan yang berpotensi besar menyempitkan sumber nafkah bagi petani, tidak diikuti dengan kompensasi atau bantuan program pengembangan masyarakat yang jelas.. Hal ini perlu mendapat perhatian serius dari pihak pemerintah dan perusahaan pemegang konsesi pertambangan untuk meredam gejolak yang berpotensi timbul di tengahtengah masyarakat, dengan memberikan kompensasi melalui program-program pembangunan di wilayah pedesaan sebagai wujud tanggung jawab sosial terhadap masyarakat yang terkena dampak langsung maupun tidak langsung dari kegiatan penambangan emas di Kabupaten Bombana.

\section{Ucapan Terimakasih}

Ucapan terimakasih kami tujukan kepada Direktorat Penelitian dan Pengabdian Kepada Masyarakat DIKTI yang telah mendanai kegiatan penelitian ini melalui Hibah Desentralisasi Penelitian Dosen Pemula tahun anggaran 2012. Terimakasih kami ucapkan pula kepada Camat Lantari Jaya dan Rarowatu Utara, Kepala Desa Langkowala, Watu-Watudan Wumbubangka yang telah memfasilitasi kami melakukan penelitian, dan masyarakat di ketiga desa tersebut atas partisipasi mereka dalam kegiatan survey dan focus group discussion.

\section{DAFTAR PUSTAKA}

Amri, U, 2010. The Dynamic of Power Contestation over Bombana's Gold Mining site, Southeast Sulawesi Province, Indonesia. Makalahdisampaikan pada $2^{\text {nd }}$ Southeast Asia Update, Tanggal 18 Juni 2010, VU University Amsterdam.

Bennett, N. (2010). Sustainable Livelihoods from Theory to Conservation Practice: An Extended Annotated Bibliography for Prospective Application of Livelihoods Thinking in Protected Area Community Research. Protected Area and Poverty Reduction Alliance Working Paper No. 1. Victoria, Canada: MPARG (UVic); PAPR (VIU).

Bebbington, A., 1998. Capital and Capabilities, A Framework for Analyzing Peasant Viability, Rural Livelihoods and Poverty. World Development vol 27 (12):2021-2044.

Biro Pusat Statistik (BPS), 2012. Kabupaten Bombanan dalam Angka 2012. BPS Kabupaten Bombana.

Brock, Karen, 1999. Implementing Sustainable Livelihoods Framework for Policy-Directed Research: Reflection on Practice in Mali. IDS Working Paper No. 90, IDS, Brigthon.

Bury, Jeffrey, 2003. Livelihoods in Transition: Transnational Gold Mining Operations and Local Change in Cajamarca, Peru. The Geographical Journal, Vol. 170 (1): 78-91.

Carney, D. 1998. Implementing the Sustainable Livelihoods Approach. Ch. 1.i D. Carney (ed). Sustainable Rural Livelihoods, What Contribution Can We Make? DFID, London.

Cartier, L.E. dan M. Burge, 2011. Agriculture and Artisanal Gold Mining in Sierra Leone: Alternatives or Complements? Journal of International Development, Vol. 23:1080-1099.

Chambers, R. 1995 Poverty and Livelihoods: Whose Reality Counts? Environment and Urbanization Vol. 7(1): 173204.

Chambers R and Conway R 1992 Sustainable Rural Livelihoods: Practical Concepts for the 21st Century IDS Discussion Paper No. 296 IDS, Brighton.
DFID (Department for International Development), 1999 Livelihoods Guidance sheets DFID, London.

Ellis, F., 2000. Rural Livelihoods and Diversity in Developing Countries. Oxford University Press, Oxford OX2 6DP.

FAO (Food and Agriculture Organization), 2007. Livelihoods Assessment and Analysis. Food Security Information for Action E-Learning Series, FAO, Rome.

Fisher, E., R. Mwaipopo, W. Matagwaba, D. Nyange, dan G. Yaron, 2009. "The Ladder that Sends Us To Wealth": Artisanal Mining and Poverty Reduction in Tanzania. Resource Policy, Vol 34 : 32-38.

Kidido, J. K., Ayitey, J. Z., Kuusaana, E. D., \& Gavu, E. K., 2015. Who is the rightful recipient of mining compensation for land use deprivation in Ghana?. Resources Policy, 43, 19-27.

Kitula, A.G.N., 2005. The Environmental and Socio-economic Impacts of Mining in Local Livelhoods in Tanzania: A Case Study Geita District. Journal of Cleaner Production 14 (2006) : 405-414.

Lasut, M.T., dkk., 2009. Distribution and Accumulation of Mercury Derived from Gold Mining in Marine Environment and Its Impact on Residents of Buyat Bay, North Sulawesi, Indonesia. Water Air Soil Pollut (2010) 208: 153-164.

Prasetyo, B., dkk., 2010. Rehabilitation of Artisanal Mining Gold Land in West Lombok, Indonesia: 2. Arbuscular Mycorrhiza Status of Tailings and Surrounding Soils. Journal of Agricultural Science Vol. 2 (2) : 202-209.

Pudjiastuti, TN., 2010. Dampak Kegiatan Penambangan Emas terhadap Sosial, Budaya dan Ekonomi Masyarakat di Bombana. Bab.3. Zulkarnain Iskandar (ed). Strategi Pengembangan Wilayah Pertambangan Rakyat di Kabupaten Bombana, Lembaga Ilmu Pengetahuan Indonesia, Jakarta.

Reddy, V. R dan J. Soussan, 2004. Assessing the Impact of Watershed Development Programmes: A Sustainable Rural Livelihoods Framework. Indian Journal of Agricultural Economics vol.59, (3): 331 - 343.

Sen, Amartya, 1997. Editorial: Human Capital and Human Capability. World Development, Vol 25 (12): 1969:1951.

Sen, Amartya, 2005. Human Rights and Capabilities. Journal of Human development, Vol. 6 (2): 151-166.

Scoones, I., 1998, 'Sustainable Rural Livelihoods: a framework for analysis', IDS Working Paper No 72: IDS, Brighton.

Schoones, I., 2006. Livelihoods Perspective and Rural Development. The Journal of Peasant Studies, vol 36(1) :171-196.

Soemarwoto, R. dan R. Ellen, 2010. Gold Mining and Changing Perception of Risk in West Java. Human Organization Vol 65 No. 3 2010, hal. 233-241.

Subiman, Nila L. danBudy P. Resosudarmo, 2010. Tambang untukKesejahteraan Rakyat: Konflikdan Usaha Penyelesaiannaya. I.J. Azis, L.M. Napitupulu,A.A. Patunru, and B.P. Resosudarmo (eds.), Pembangunan Berkelanjutan: Peran dan Kontribusi Emil Salim. Jakarta: Kepustakaan Populer Gramedia, hal. 426-459.

Sukhyar, 2008. Selamatkan Bangsa dengan Membangun Kesejahteraan Masyarakat dan Linkungan melalui Sultra sebagai Provinsi Nikel dan Aspal. Makalah disampaikan Simposium Nasional Pertambangan pada Universitas Muhammadiyah Kendari, 10 Juli 2008 : 12-15.

Zulkarnai, Iskandar, dkk., 2010. Strategi Pengembangan Wilayah Pertambangan Rakyat di Bombana, Sulawesi Tenggara. Lembaga Ilmu Pengetahuan Indonesia (LIPI), Jakarta.

Zulkifli, 2013. Analisis Dampak Sosial, Ekonomi, Budaya dan Kesehatan Masyarakat Akibat Penambngan Emas di Kecamatan Sawang Aceh Selatan. Jurnal Ekonomika, Vol 4(17): 8-15. 